\title{
Variation in the $\beta$-Carotene and Ascorbic Acid Contents of Lettuce and Carrots as Influenced by Seasonal Changes in Puerto Rico
}

\author{
María del C. C. Fernández ${ }^{1}$
}

INTRODUCTION

The demand for high-quality vegetables, and the knowledge obtained from the work conducted in other countries that plants and vegetables are important sources of vitamins, led to a study of those factors responsible for variations in the $\beta$-carotene (provitamin A) and ascorbic acid (vitamin C) contents of some of our food crops, which are affected by our tropical conditions. Factors to consider are the rainy season which extends from May to December; the drought occurring from January to April, which is sometimes rather severe; and the fact that most crops are cultivated all year-round in a country where there are some seasonal variations between winter and summer. Light intensity is very high, reaching sometimes close to 17,000 to 19,000 foot-candles during the summer months, according to Guiscafré-Arrillaga $(1),{ }^{2}$ as compared to a maximum of 10,000 to 12,000 foot-candles in the Temperate Zone.

Variations in the vitamin content of plants during any given period of growth may result from the action or interaction of one or several factors such as soil and climatic conditions, and heredity. It is not yet clearly understood how the various climatic factors such as light intensity, temperature of soil and air, relative humidity, soil moisture, and atmospheric pressure affect the vitamin content of plants. Rain and wind velocity appear to exert their effect through their action on one or more of the abovementioned factors.

\section{REVIEW OF THE LITERATURE}

The data reported from several regions indicated that variations in the carotene content of carrots were related to variety, the stage of growth and development, and the prevailing environment during the growing season.

According to French and Abbott (2) some subtropical fruits, such as the pink guava and the mango, are high in both carotene and ascorbic acid content. Nevertheless, Bernstein et al. (3) found that factors which led to a

1 Associate Nutritionist, Agricultural Experiment Station, University of Puerto Rico, Río Piedras, P.R.

Italic numbers in parenthesis refer to Literature Cited, pp. 47-8. 
high ascorbic acid content in turnip greens, resulted in a low carotene ccntent and vice versa.

Atkenson et al. (4) found that pasture plants had a relatively high carotene content during early summer, which markedly decreased during the midsummer months.

The studies on the effects of environment made by Hamner, Lyon, and Hamner (5); Ellis and Hamner (6); Murphy (7); and Hamner, Bernstein, and Maynard (8), on the vitamin content of tomatoes; those of Reder, Ascham, and Eheart ( 9 ) on the vitamin content of turnip greens; and those of Hansen (10), Janes (11), and Eheart et al. (12), working with carrots, cabbage, and beans, all indicate that climatic conditions have a greater effect on the relative content of vitamins than do variety, soil conditions, and fertilizers.

\section{MATERIAL AND METHODS}

Lettuce (var. Black Seeded Simpson) and carrots (var. Danver's Half Long) were grown at the Agricultural Experiment Station of the University of Puerto Rico, at Rio Piedras, and analyzed for $\beta$-carotene and ascorbic acid. A chemical fertilizer 10-10-5 and filter-press cake were applied to the field before planting. To minimize the differences in soil fertility across the field these crops were grown in replicated plots $10 \times 4$ feet, and randomized from top, middle, and bottom of each plot.

In the beginning, 10 replications were made of each crop, but these were reduced to 5 after a statistical study indicated that this number provided enough data for the analysis. Plantings were made and harvested at approximately monthly intervals. Lettuce was collected 30 days, and carrots 90 days after plantings.

Plants were collected and brought into the laboratory before 9:00 a.m. Lettuce tops were separated from the roots and washed under tapwater, dried, and prepared for extraction at once. Carrot tops were removed and the tops were washed and dried following the same procedure as for lettuce.

The percentage dry weight was determined by drying at $65^{\circ} \mathrm{F}$. until constant weight was attained.

$\beta$-carotene determinations were made by the Official and Tentative Methods of Analysis of the Association of Official Agricultural Chemists, 6th ed., 1945, using a Coleman Universal spectrophotometer.

Ascorbic acid determinations were made by grinding the samples with a mortar and pestle, with the aid of acid-washed sand, using an 8-percent metaphosphoric acid solution, and then titrating with 2,4-dichlorophenolindophenol solution which was standardized against pure ascorbic acid. 


\section{RESULTS}

EFFECTS OF TEMPERATURE, NUMBER OF RAINY DAYS, AND RAINFALL

No statistically significant correlation was found between the monthly $\beta$-carotene content of lettuce or carrots and the mean temperature, number of rainy days, or rainfall, when these factors were measured for the length of the entire growing period.

The monthly variations in the carotene content of lettuce and carrots are shown in table 1.

TABLE 1.- $\beta$-carotene content of lettuce and carrots ( $\mu$ g. per gram) grown in 2 conseculive years, $1945-48$

\begin{tabular}{|c|c|c|c|c|}
\hline \multirow{3}{*}{ Month harvested } & \multicolumn{4}{|c|}{$\beta$-carotene content of - } \\
\hline & \multicolumn{2}{|c|}{ Lettuce } & \multicolumn{2}{|c|}{ Carrots } \\
\hline & Fresh weight & Dry weight & Fresh weight & Dry weight \\
\hline 1945 & & & & \\
\hline $\begin{array}{c}\text { December } \\
1946\end{array}$ & 58 & 1,040 & 109 & 1,042 \\
\hline January & 41 & 658 & - & 一 \\
\hline February & 66 & 1,043 & - & - \\
\hline March & 79 & 1,235 & 146 & 1,201 \\
\hline April & 70 & 1,212 & 110 & 1,097 \\
\hline May & 62 & 875 & - & 一 \\
\hline June & 63 & 861 & 77 & 610 \\
\hline July & 124 & 1,475 & 120 & 1,071 \\
\hline August & 63 & 809 & 99 & 975 \\
\hline September & 30 & 487 & - & - \\
\hline October & 34 & 493 & - & - \\
\hline November & 35 & 521 & - & - \\
\hline $\begin{array}{c}\text { Jecember } \\
1947\end{array}$ & 56 & 904 & 51 & 515 \\
\hline January & 32 & 631 & 97 & 877 \\
\hline February & 54 & 1,047 & 199 & 1,870 \\
\hline March & 131 & 2,307 & 77 & 807 \\
\hline April & 50 & 884 & 89 & 795 \\
\hline May & 45 & 769 & 83 & 821 \\
\hline June & 50 & 801 & 97 & 845 \\
\hline July & 59 & 851 & 59 & 428 \\
\hline August & 54 & 880 & 79 & 733 \\
\hline September & 50 & 838 & 44 & 431 \\
\hline October & 60 & 1,003 & 38 & 368 \\
\hline November & 41 & 693 & 36 & 361 \\
\hline December & 29 & 694 & 63 & 617 \\
\hline $\begin{array}{c}1948 \\
\text { January }\end{array}$ & 38 & 731 & - & - \\
\hline
\end{tabular}


The ascorbic acid content of lettuce and carrots varied somewhat from month to month, but no consistent trends were established. (See table 2.)

When the mean temperature, number of rainy days, and rainfall were measured 10 days prior to harvest, an inverse correlation was found between the $\beta$-carotene content of lettuce and the climatic factors studied as follows:

Percentage variation in $Y$ explained by $A$, and $B$ $42.22^{1}$

Percentage variation in $Y$ explained by $A$ $16.74^{1}$

Percentage additional variation in $Y$ explained by $B$ $25.48^{1}$

TABLE 2.-Ascorbic acid content $(\mathrm{mg} .100 \mathrm{gm}$.) of lettuce and carrots grown in 2 consecutive years, $1947-49$

\begin{tabular}{|c|c|c|}
\hline \multirow{2}{*}{ Month harvested } & \multicolumn{2}{|c|}{ Ascorbic acid content of- } \\
\hline & Lettuce, fresh-weight basis & Carrots, fresh-weight basis \\
\hline \begin{tabular}{l}
\multicolumn{1}{c}{1947} \\
January \\
February \\
March \\
April \\
May \\
June \\
July \\
August \\
September \\
October \\
November \\
December \\
$\quad$ 1948 \\
January \\
February \\
March \\
April \\
May \\
June \\
July \\
August \\
September \\
October \\
November \\
December \\
1949 \\
January \\
February \\
March \\
April
\end{tabular} & $\begin{array}{r}13.95 \\
11.22 \\
12.52 \\
11.22 \\
10.92 \\
14.13 \\
9.16 \\
1.51 \\
11.20 \\
13.44 \\
9.27 \\
4.07 \\
\\
4.81 \\
6.81 \\
8.41 \\
8.49 \\
12.50 \\
6.89 \\
11.12 \\
12.88 \\
9.01 \\
7.92 \\
15.58 \\
6.19 \\
15.84 \\
4.45 \\
13.47 \\
10.75\end{array}$ & $\begin{array}{l}8.3 \\
5.4 \\
6.0 \\
4.8 \\
5.6 \\
6.0 \\
4.3 \\
5.3 \\
4.4 \\
- \\
6.1 \\
8.4 \\
\\
7.4 \\
4.9 \\
1.6 \\
5.9 \\
2.9 \\
5.7 \\
4.7 \\
3.8 \\
4.1 \\
4.4 \\
5.2 \\
3.9 \\
4.7 \\
5.0 \\
- \\
-\end{array}$ \\
\hline
\end{tabular}


Percentage variation in $Y$ explained by $A, B$, and $C$

$46.17^{1}$

Percentage variation explained by $A$ and $B$

Percentage variation in $Y$ explained by $C$

1.95 (N.S.)2

Regression coefficients:

। $A=-66.7650$ (mean temperature)

$\mathrm{B}=-83.1188$ (number of rainy days)

$C=-22.1566$ (rainfall)

$Y=-\mu \mathrm{g} . \beta$-carotene per $100 \mathrm{gm}$. of fresh sample

1 Significant at the 5-percent level.

2 Nonsignificant.

The $\beta$-carotene content of carrots was not affected by the mean temperature, number of rainy days, or rainfall, when these factors were measured 10 days prior to harvest. Nevertheless, there was a marked increase in the vitamin content during March and April in the first year, and in February in the second year.

\section{EFFECT OF SUNLIGHT ON PLANTS GROWN UNDER $2 / 3$ SHADE AND UNDER NATURAL CONDITIONS}

An experiment was conducted to study further the effect of light intensity on the $\beta$-carotene and ascorbic acid content of lettuce (var. Black Seeded Simpson) and carrots (var. Danver's Half Long). The field was divided into two symmetrical sets of plots $10 \times 5$ feet each, in such a manner as to allow five replications of each crop. Plantings and harvests were made at approximate monthly intervals. Lettuce was collected 30 days and carrots 90 days after plantings. One set of plots received full exposure to sunlight, whereas the other set was covered with cheesecloth to reduce the light to two-thirds that of the adjacent plots. There were no facilities to measure light intensity when these studies were conducted.

The monthly variations in $\beta$-carotene and ascorbic acid contents of lettuce and carrots are shown in table 3.

The statistical study of the data demonstrated no significant differences in the $\beta$-carotene content of lettuce as between the shaded and unshaded plants. On the other hand, as shown in table 4, the ascorbic acid content differed significantly at the 5-percent level between the shaded and unshaded plants. The plants under shade contained less ascorbic acid than those grown under natural conditions of sunlight. (See fig. 1,A.)

Figure 1,B shows the maximum $\beta$-carotene content of lettuce occurring during October, $481.55 \mu \mathrm{g} . / 100 \mathrm{gm}$. of dry sample, and during January with approximately $521 \mu \mathrm{g} . / 100 \mathrm{gm}$. of dry sample, and February with $456.24 \mu \mathrm{g}$. $/ 100 \mathrm{gm}$. of dry sample in the unshaded plants, as compared with 


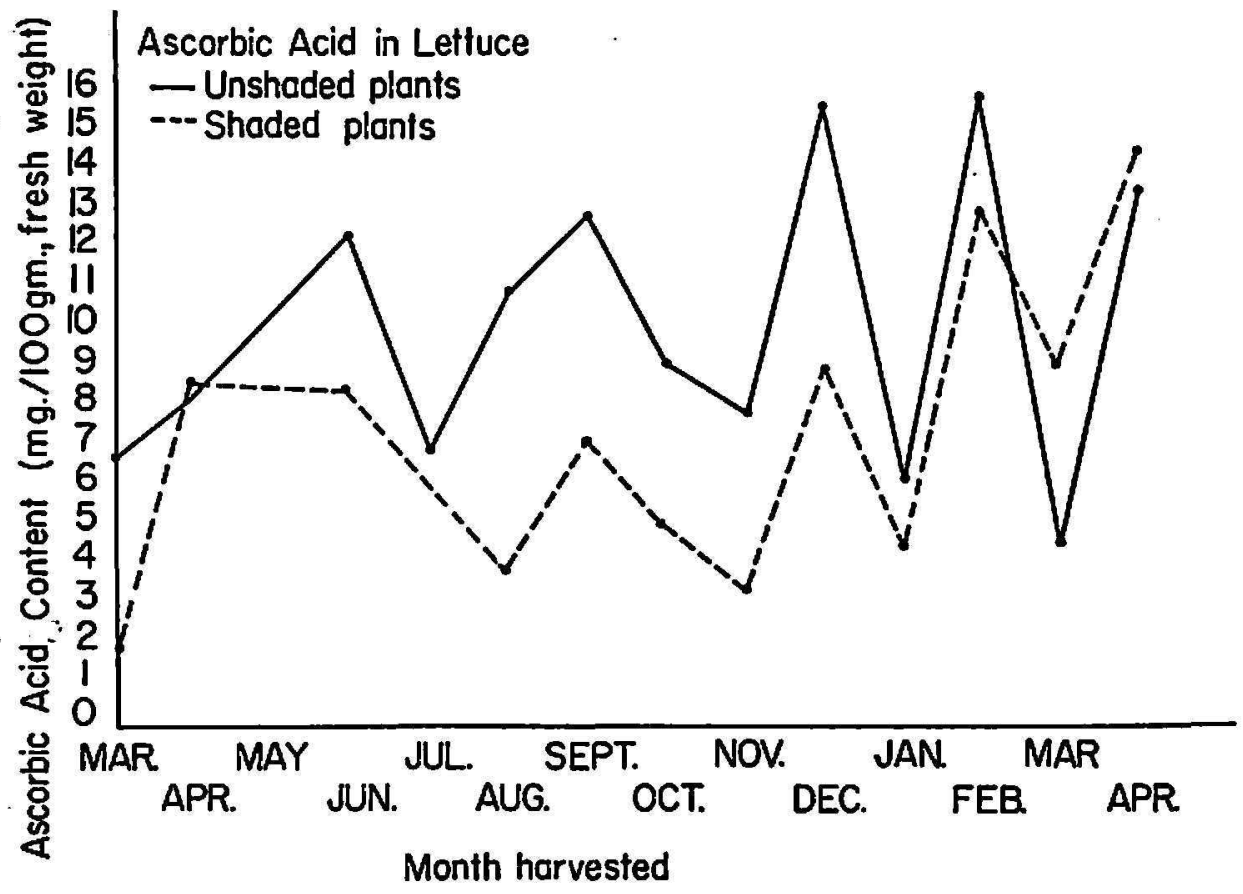

A

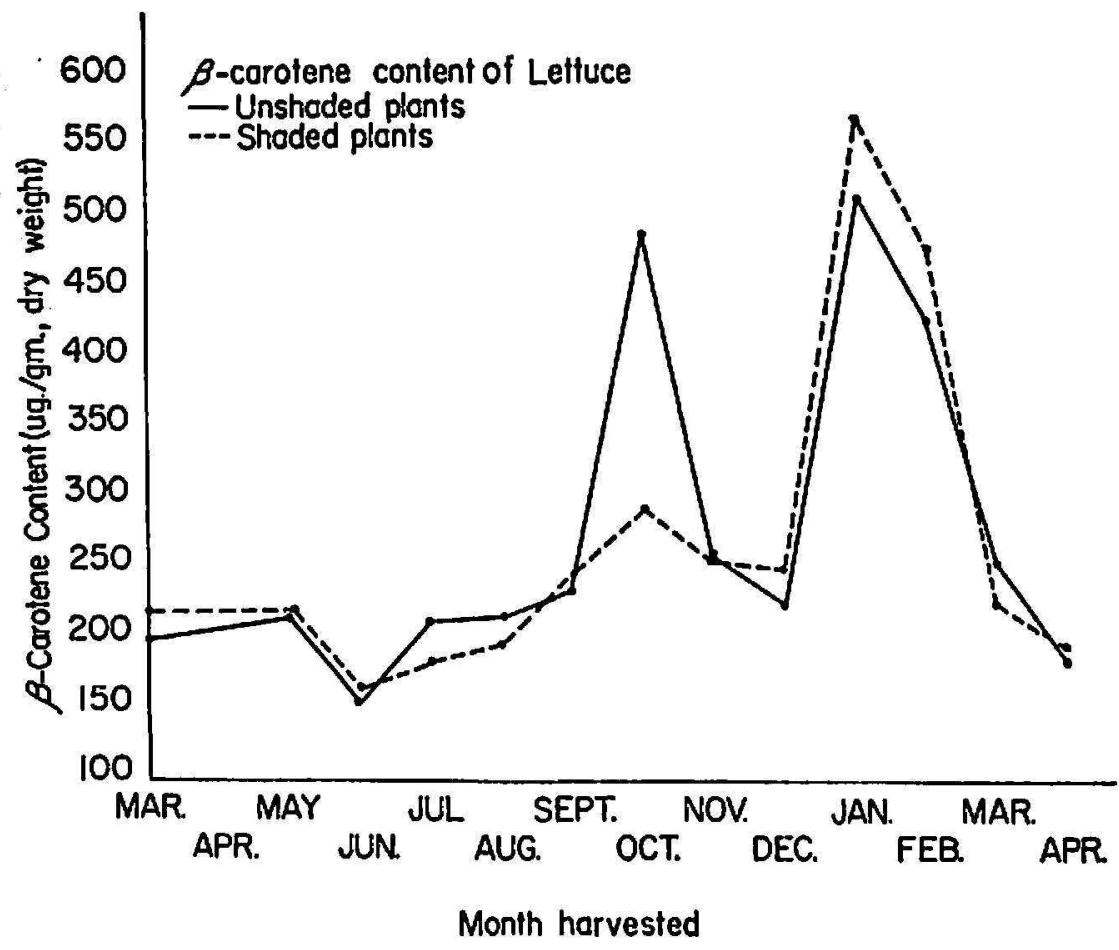

B

Fig. 1.-A, Ascorbic acid content of lettuce grown in full sunlight and under $2 / 3$ shade in the field; $B, \beta$-carotene content of lettuce grown under full sunlight and under $2 / 3$ shade in the field. 
$571.27 \mu \mathrm{g} . / 100 \mathrm{gm}$. of dry sample in January and $483.24 \mu \mathrm{g} . / 100 \mathrm{gm}$. of dry sample in the shaded plants.

No significant effect was obtained insofar as the $\beta$-carotene and ascorbic acid contents of carrots were concerned that could be attributed to the conditions under study. (See table 5.)

TABLE 3.- $\beta$-carotene and ascorbic acid content of letluce as cultivated in the sun and in 33-shaded plots in the field, 1948-49

\begin{tabular}{|c|c|c|c|c|c|c|}
\hline \multirow{3}{*}{ Month harvested } & \multicolumn{4}{|c|}{$\beta$-carotene content of- } & \multicolumn{2}{|c|}{ Ascorbic acid content } \\
\hline & \multicolumn{2}{|c|}{ Unshaded plants } & \multicolumn{2}{|c|}{ Shaded plants } & \multirow{2}{*}{$\begin{array}{c}\begin{array}{c}\text { Unshaded } \\
\text { plants }\end{array} \\
\begin{array}{c}\text { Fresh } \\
\text { weight }\end{array}\end{array}$} & \multirow{2}{*}{$\begin{array}{c}\begin{array}{c}\text { Shaded } \\
\text { Plants }\end{array} \\
\begin{array}{c}\text { Dry } \\
\text { weight }\end{array}\end{array}$} \\
\hline & $\begin{array}{c}\text { Fresh } \\
\text { weight }\end{array}$ & $\underset{\text { weight }}{\text { Dry }}$ & $\begin{array}{l}\text { Fresh } \\
\text { weight }\end{array}$ & $\underset{\text { weight }}{\text { Dry }}$ & & \\
\hline 1948 & $\mu \mathrm{s} / \mathrm{gm}$. & $\mu g . / m g$. & $\mu g . / \mathrm{gm}$. & $\mu g . / g m$. & $3 f g . / g m$. & $\mathbf{~ I r g . / g m . ~}$ \\
\hline March & 14.16 & 208.84 & 14.10 & 220.54 & 6.81 & 1.97 \\
\hline April & - & - & - & - & 8.41 & 8.62 \\
\hline May & 13.87 & 216.21 & 14.37 & 221.34 & - & - \\
\hline June & 10.34 & 152.34 & 10.43 & 165.76 & 12.50 & 8.49 \\
\hline July & 14.22 & 215.29 & 11.47 & 187.54 & 6.89 & 6.27 \\
\hline August & 14.88 & 218.38 & 12.35 & 194.61 & 11.12 & 3.93 \\
\hline September & 14.82 & 237.04 & 13.40 & 249.88 & 12.88 & 7.23 \\
\hline October & 27.71 & 481.50 & 15.64 & 298.54 & 9.01 & 5.01 \\
\hline November & 14.71 & 263.10 & 13.18 & 255.80 & 7.82 & 3.36 \\
\hline $\begin{array}{c}\text { December } \\
1949\end{array}$ & 12.67 & 230.85 & 12.41 & 255.52 & 15.58 & 9.01 \\
\hline January & 28.22 & 520.87 & 29.62 & 571.27 & 6.19 & 4.36 \\
\hline February & 28.29 & 456.24 & 29.58 & 483.24 & 15.84 & 13.12 \\
\hline March & 16.41 & 264.49 & 15.47 & 233.20 & 4.45 & 9.05 \\
\hline April & 10.80 & 191.75 & 11.39 & 207.75 & 13.47 & 14.37 \\
\hline
\end{tabular}

\section{SUMMARY}

1. Climatic factors such as temperature, number of rainy days, and total rainfall, apparently have no effect on the synthesis of $\beta$-carotene and ascorbic acid in lettuce and carrots, when these are determined during the entire growing period.

2. The ascorbic acid content of lettuce is inversely correlated with the sunlight received by the plant some 10 days prior to harvest.

3 . Solar radiation received by lettuce plants during October, January, and February seems to be more favorable to the $\beta$-carotene synthesis than that received during the rest of the year. Days are longer, but solar radiation is milder during this time of the year. 
4. Solar radiation in Puerto Rico favors ascorbic acid synthesis in lettuce all year through.

5. Results obtained under the conditions of these studies demonstrate that temperature, number of rainy days, and rainfall have no effect on the $\beta$-carotene and ascorbic acid content of carrots.

TABLE 4.- $\beta$-carotene and ascorbic acid content of letluce as cultivated under full sunlight and in 3/3-shaded plots in the field, 1946-47

\begin{tabular}{|c|c|c|c|c|c|c|}
\hline \multirow{2}{*}{ Month harvested } & \multicolumn{3}{|c|}{$\beta$-carotene content, fresh-weight basis } & \multicolumn{3}{|c|}{$\begin{array}{c}\text { Ascorbic acid content, fresh-weight } \\
\text { basis }\end{array}$} \\
\hline & 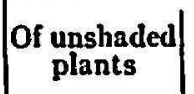 & $\begin{array}{l}\text { Of shaded } \\
\text { plants }\end{array}$ & Difference & $\begin{array}{c}\text { Of unshaded } \\
\text { plants }\end{array}$ & $\begin{array}{c}\text { Of shaded } \\
\text { plants }\end{array}$ & Difference \\
\hline 1946 & $\mu g . / g m$. & $\mu g . / g m$. & $\mu \mathrm{g} / . \mathrm{g} m$. & $\mathrm{Mg} . / 100 \mathrm{gm}$. & Alg./100 gm. & $1 \mathrm{gg} / 100 \mathrm{gm}$. \\
\hline March & 14.10 & 14.10 & 0.06 & 6.81 & 1.97 & 4.84 \\
\hline April & 一 & - & - & 8.41 & 8.62 & .21 \\
\hline May & 13.87 & 14.37 & .50 & 12.50 & 8.49 & 4.01 \\
\hline June & 10.34 & 10.43 & .09 & 6.89 & 6.27 & .62 \\
\hline July & 14.22 & 11.47 & 2.75 & 11.12 & 3.93 & 7.19 \\
\hline August & 14.82 & 13.40 & 1.42 & 12.88 & 7.23 & 5.65 \\
\hline September & 27.71 & 15.64 & 12.07 & 9.01 & 5.01 & 4.00 \\
\hline October & 14.71 & 13.18 & 1.53 & 7.82 & 3.36 & 4.46 \\
\hline November & 12.67 & 12.41 & .26 & 15.58 & 9.01 & 6.57 \\
\hline $\begin{array}{c}\text { December } \\
1947\end{array}$ & 28.22 & 29.62 & 1.40 & 6.19 & 4.36 & 1.83 \\
\hline January & 28.29 & 29.58 & 1.29 & 15.83 & 13.12 & 2.72 \\
\hline February & 16.41 & 15.47 & .94 & 4.45 & 9.05 & 4.60 \\
\hline March & 10.80 & 11.39 & .59 & 13.47 & 14.47 & .90 \\
\hline Totals & 221.10 & 203.41 & 17.69 & 130.97 & 94.79 & 36.18 \\
\hline \multirow[t]{2}{*}{ Means } & 17.01 & 15.65 & 1.36 & 10.07 & 7.29 & 2.78 \\
\hline & \multicolumn{3}{|c|}{$\begin{array}{l}\text { Standard error of the dif- } \\
\text { ference }=0.9645 \mu \mathrm{g} . / \mathrm{gm} \text {. } \\
t=1.410 \text { (not significant) }\end{array}$} & \multicolumn{3}{|c|}{$\begin{array}{l}\text { Standard error of the dif }- \\
\quad \text { ference }=0.9290 \mu \mathrm{g} . / \mathrm{gm} \text {. } \\
t=2.992\end{array}$} \\
\hline
\end{tabular}

\section{RESUMEN}

1. Factores de clima tales como la temperatura ambiental, el número de días lluviosos, y la cantidad total de lluvia recibida durante el período de crecimiento demostraron no tener efecto significativo en la sintesis de $\beta$-caroteno y ácido ascórbico en la lechuga.

2. El contenido de ácido ascórbico en la lechuga está inversamente 
correlacionado con la luz solar recibida por la planta durante 10 días antes de la cosecha.

3. La cantidad de luz solar durante octubre, enero y febrero es más favorable a la síntesis de $\beta$-caroteno en la lechuga, que la del resto del año. Durante estos meses la luz solar es de menor intensidad, pero los días son más largos.

TABLE 5.- $\beta$-carotene and ascorbic acid content of carrols cullivated under full sunlight and in 3/3-shaded plots in the field, 1948-49

\begin{tabular}{|c|c|c|c|c|c|c|}
\hline \multirow{2}{*}{ Month harvested } & \multicolumn{3}{|c|}{$\beta$-carotene, fresh-weight basis } & \multicolumn{3}{|c|}{ Ascorbic acid, fresh-weight basis } \\
\hline & $\begin{array}{c}\text { Unshaded } \\
\text { plants }\end{array}$ & $\begin{array}{l}\text { Shaded } \\
\text { plants }\end{array}$ & Difierence & $\begin{array}{c}\text { Unshaded } \\
\text { plants }\end{array}$ & $\begin{array}{l}\text { Shaded } \\
\text { plants }\end{array}$ & Difference \\
\hline \multicolumn{7}{|c|}{ $1 / \mathrm{g} . / 100 \mathrm{gm} .|M \mathrm{~g} . / 100 \mathrm{gm}.| \mathrm{Mg} . / 100 \mathrm{gm}$} \\
\hline May & 34.17 & 28.48 & 5.69 & 4.91 & 6.38 & -1.47 \\
\hline June & 27.71 & 32.13 & -4.42 & 1.45 & 1.04 & .41 \\
\hline July & 39.18 & 43.42 & -4.24 & 5.87 & 6.57 & -.70 \\
\hline August & 33.25 & 42.42 & -9.17 & 2.89 & 2.36 & .53 \\
\hline September & 28.25 & 28.02 & .61 & 5.72 & 5.59 & .13 \\
\hline October & 18.02 & 14.59 & 3.42 & 4.74 & 4.77 & .03 \\
\hline November & 26.95 & 23.08 & 3.89 & 3.84 & 3.92 & -.08 \\
\hline $\begin{array}{c}\text { December } \\
1949\end{array}$ & 27.45 & 25.19 & 2.26 & 4.05 & 3.36 & .69 \\
\hline January & 52.56 & 37.43 & 15.13 & 4.43 & 3.43 & .90 \\
\hline February & - & - & - & 5.24 & 5.38 & -.14 \\
\hline March & - & - & - & 3.82 & 4.50 & -.68 \\
\hline Totals & 287.92 & 274.74 & 13.18 & 46.96 & 47.40 & -0.44 \\
\hline \multirow[t]{2}{*}{ Means } & 31.99 & 30.53 & 1.46 & 4.27 & 4.31 & -0.04 \\
\hline & \multicolumn{3}{|c|}{$\begin{array}{l}\text { Standard error of dif- } \\
\text { ference }=2.3451 \mu \mathrm{g} . / \mathrm{gm} . \\
\ell=0.623 \text { (not significant) }\end{array}$} & \multicolumn{3}{|c|}{$\begin{array}{l}\text { Standard error of dif } \\
\text { ference }=0.2105 \mathrm{mg} . / 100 \\
\mathrm{gm} . \\
t=0.190 \text { (not significant) }\end{array}$} \\
\hline
\end{tabular}

4. La intensidad de la luz solar en Puerto Rico favorece la sintesis del ácido ascórbico en la lechuga durante todo el año.

5. Los resultados obtenidos bajo las condiciones experimentales de estos estudios demuestran que la temperatura ambiental, los días lluviosos y la lluvia total recibida no tienen efecto alguno sobre la cantidad de $\beta$-caroteno y ácido ascórbico en la zanahoria.

\section{LITERATURE CITED}

1. Guiscafré-Arrillaga, J., and Gómez, L. A., Effect of solar radiation on the vegetative growth and yield of coffee, J. Agr. Univ. P.R. 26 (4) 73-90, 1942. 
2. French, R. B., Abbott, O. D., Levels of carotene and ascorbic acid in Floridagrown foods, Fla. Agr. Expt. Sta. B. 444, 1948.

3. Bernstein, L., Hamner, K. C., and Parkwe, R. W., The influence of mineral nutrition, soil fertility, and climate on carotene and ascorbic acid content of turnip greens, Plant Physiol. 20 540-72, 1945.

4. Atkenson, F. W., Peterson, W. J., and Aldous, A. R., Observations on the carotene content of some typical pasture plants, $J$. Diary Sci. 20 557-62, 1937.

5. Hamner, K. C., Lyon, C. B., and Hamner, L. C., Effect of mineral nutrition on the ascorbic acid of the tomato, Bot. Gaz. 103 585-616, 1942.

6. Ellis, G. H., and Hamner, K. C., The carotene content of tomatoes influenced by various factors, $J$. Nutr. $25539-53,1943$.

7. Murphy, E., Vitamin C and light, Proc. Amer. Soc. Hort. Sci. 36 498-9, 1939.

8. Hamner, K. C., Bernstein, L., and Maynard, L. A., Effect of light intensity, day length, temperature, and other environmental factors on the ascorbic acid content of tomatoes, $J$. Nulr. 29 85-96, 1945.

9. Reder, R. L., Ascham, L. A., and Eheart, M. S., Effect of fertilizer and environment on the ascorbic acid content of turnip greens, J. Agr. Res. 66 375, 1943.

10. Hansen, E., Variation on the carotenc content of carrots, Proc. Amer. Soc. Hort. Sci. 46 355-8, 1945.

11. Janes, B. E., The relative effect of variety and environment in determining the variations of percent dry weight, ascorbic acid, and carotene content of cabbage and beans, Proc. Amer. Soc. Hort. Sci. 45 387-90, 1944.

12. Eheart, J. F., Moore, R. C., Speirs, M., Cowart, F. F., Cochran, H. L., Sheets, O. A., Mc Whirter, L., Gieger, M., Bowers, J. L., Heinze, P. H., Hayden, F. R., Mitchell, J. H., and Carolus, R. L., Vitamin Studies on Lima Beans, South. Co-op. Group. Ser. 5, 24 pp., 1946. 